\title{
Window of opportunity of Liparis loeselii populations during vegetation succession on the Wadden Sea islands
}

\author{
Ab Grootjans ${ }^{1,2} \cdot$ Rohani Shahrudin ${ }^{3} \cdot$ Annelies van de Craats $^{4}$. \\ Annemieke Kooijman ${ }^{4} \cdot$ Gerard Oostermeijer $^{4}$ • Jörg Petersen ${ }^{5}$ - Donovan Amatirsat ${ }^{6}$. \\ Chantal Bland $^{6} \cdot$ Pieter Stuyfzand $^{6,7}$
}

Received: 26 September 2015 / Revised: 16 March 2016 / Accepted: 22 June 2016 /Published online: 2 July 2016

(C) The Author(s) 2016. This article is published with open access at Springerlink.com

\begin{abstract}
The present study aims at assessing the life span of populations of the orchid L. loeselii during successional in dune slacks on the Wadden Sea islands. An inventory of Liparis loeselii populations was carried out on 6 islands, while the population structure was assessed in more detail on the island of Texel. The occurrence of the orchid was related to soil factors and hydrological conditions. Groundwater levels were measured in a dune area with natural dune slack formation. The groundwater composition was analyses and the freshwater lenses were modelled. Various scenarios were investigated, including sea level rise and sand nourishment. The window of opportunity for $L$. loeselii to colonize a new slack is relatively narrow. Under favorable management, the population can survive c. 20 years. Soil $\mathrm{pH}$ was positively correlated with the occurrence of $L$. loeselii populations, while a high organic matter content was negatively correlated. Sites with large populations of $L$. loeselii, were situated in young
\end{abstract}

Ab Grootjans

A.P.Grootjans@rug.nl

1 Centre for Energy and Environmental Studies, University of Groningen, Nijenborgh 4, 9747, AG Groningen, The Netherlands

2 Institute for Wetland and Water research, Radboud University Nijmegen, Heyendaalseweg 135, 6525, ED Nijmegen, The Netherlands

3 School of Marine and Environmental Sciences, Universiti Malaysia Terengganu, Kuala Terengganu, Malaysia

4 Institute for Biodiversity and Ecosystem Dynamics (IBED), University of Amsterdam, Science Park, 904 Amsterdam, The Netherlands

5 Nature-consult, Hildesheim, Germany

6 VU University Amsterdam, Amsterdam, The Netherlands

7 Kiwa, Water Research (KWR), Nieuwegein, The Netherlands dune slacks, that functioned as flow-through lakes and has top soilsinfluenced by anoxic calcareous groundwater. Modelling showed that the freshwater lens would decrease due to sea level rise, while artificial sand nourishment could counteract this effect. The populations of the Hors area on Texel, the Netherlands, can survive for several decades due to continuous formation of new slacks. Discharge of calcareous groundwater is essential to keep the $\mathrm{pH}$ on a high level. The hydrological systems that supply dune slack with groundwater are relatively small and are vulnerable for changes in sea level rise.

Keywords Hydrology · Landscape dynamics · Sand nourishment $\cdot$ Soil organic carbon $\cdot$ Sea level rise $\cdot$ Successional age

\section{Introduction}

Liparis loeselii loeselii (L.) Rich. is a small orchid which in coastal wetlands (interdunal slacks) thrives on mineral soils (Jones \& Etherington 1992, Lammerts \& Grootjans 1998, Petersen 2000, Oostermeijer \& Hartman 2014). It is also encountered in low-productive, calcareous peatlands (fens) (Wheeler et al. 1998, McMaster 2001, Pawlikowski 2008, Naczk \& Minasiewicz 2010, Milanović 2012, Oostermeijer \& Hartman 2014), and in purely man-made habitats, such as gravel-pits (Bzdon \& Ciosek 2006) or excavated peatlands (Wheeler et al. 1998). Liparis loeselii has a wide distribution, ranging from the northeast of the United States and Canada, to northern and Central European countries, Russia and even several localities in Siberia. Despite this wide distribution area, populations of $L$. loeselii are in serious decline along most of its geographical range. However, as yet, few demographic studies have been published in relation to changes in 
environmental conditions (e.g. Jones et al. 1995, Jones 1998, Wheeler et al. 1998, McMaster 2001, Oostermeijer \& Hartman 2014). In Central Europe it is now considered as an endangered species (Schnittler \& Günther 1999) and has been listed in Annex II and Annex IV of the Council Directive 92/ 43/EEC on the Conservation of natural habitats, thus making it a priority species for conservation in most European countries.

The relationship between $L$. loeselii survival and successional stage in coastal dune slacks in Wales was studied by Jones and Etherington (1992). They found that L. loeselii appeared between 12 and 15 years after initial vegetation establishment of the slacks. The orchid started to decline when the shrub, Salix repens, developed a dense vegetation cover, which occurred after around 40 years. Several authors have indicated that $L$. loeselii populations cannot survive when the habitat is overgrown by woody species, or even mosses ((Jones and Etherington 1992, McMaster 2001, Bzdon and Ciosek 2006). In addition to habitat age and vegetation factors, abiotic factors such as water level and $\mathrm{pH}$, have also been mentioned in the literature to be important factors that influence the survival and population density of this orchid (Oostermeijer \& Hartman 2014). These authors also found that the population life span of the species was generally very short, between 5 and 15 years. Jones (1998) reported the decline of this orchid as a consequence of too low water levels during summer, whereas Oostermeijer and Hartman (2014) reported declines of the species in years with a high water table. Favorable conditions recorded for $L$. loeselii populations include a high $\mathrm{pH}(6-7)$ combined with low availability of nutrients (Wheeler 1998). On the Dutch and German Wadden Sea islands such conditions are present when exfiltrating groundwater is present with relatively high concentrations of calcium and bicarbonate (Petersen 2000, Davy et al. 2006). Stuckey (1967) showed a wider range of favorable $\mathrm{pH}$ values for populations in the United States (4.6-7.2).

In this study we will present an overview of the occurrence of Liparis loeselli on the Dutch and German Wadden Sea islands, in relation to environmental factors and successional age. Successional age is defined here as the period since the first establishment of vegetation in a dune slack. We are particularly interested in the 'window of opportunity' within an ongoing succession. A window of opportunity is the time period in which a species is able to establish, a population and to maintain the population. We studied both dune slacks that are regularly managed (mowing) and slacks that are not managed, but where successional age is only determined by the rate of renewed formation of natural dune slacks. For this we focus on a series of dune slacks on the southern tip of Texel, the Netherlands, which is a good model system to study the occurrence of this orchid during different successional stages. We specifically addressed two questions: (i) what is the window of opportunity for $L$. loeselii under regular mowing of the vegetation compared to a strategy of Dynamic Coastal Management in which natural processes create new dune slacks?, and (ii) which eco-hydrological conditions are favourable for the long-term survival of $L$. loeselii populations on the Wadden Sea islands?

\section{Material \& methods}

\section{Study areas}

This study was conducted on the Dutch Wadden Sea Islands of Texel, Vlieland, Terschelling, Ameland, Schiermonnikoog and the German island of Borkum. Here we studied the occurrence of $L$. loeselii populations in relation to environmental factors. Also sites were studied from which the species had become extinct and sites where new population establishment can be expected. On Texel we also studied the population development of $L$. loeselii at the southern tip of the island, (the Hors, $52^{\circ} 59^{\prime} \mathrm{N}, 4^{\circ} 44^{\prime} \mathrm{E}$ ), in relation to successional age, environmental factors and hydrological system (Fig. 1). The Hors is a very young dune area with a very broad beach plain, that enables the formation of embryonic dune systems and small dune ridges that are able to enclose new slacks. Some of these slacks are not entirely natural, as they are enclosed by several sand dikes that were created artificially by the coastal protection agency (RWS) in the mid-1970's. Seven sites were selected in the Hors area. Site selection was based on dune slack age and the current, former of future occurrence of L. loeselii (Fig. 1). One site was studied from which the species had disappeared; another was selected in an area where we would expect new population establishment in the near future. The latter site comprised a very young dune slack which was occasionally flooded with sea water but already starting to develop a dune slack vegetation, while also supporting several halophytes, such as Glaux maritima, Bolboschoenus maritimus, Juncus maritimus and Oenanthe lachenallii.

\section{Estimation of successional age of dune slacks}

In order to estimate the age of dunes and dune slacks in the Hors area, we used information from historical maps, aerial photographs and information obtained from field observations recorded by officials of the National Forestry Service (Staatsbosbeheer).

\section{Inventory of Liparis loeselii populations on the Wadden Sea islands}

In 2010 populations of $L$. loeselii were counted in the context of a study on genetic differentiation of the orchid on the Dutch Wadden Sea islands (Shahrudin 2014). Estimation of the 

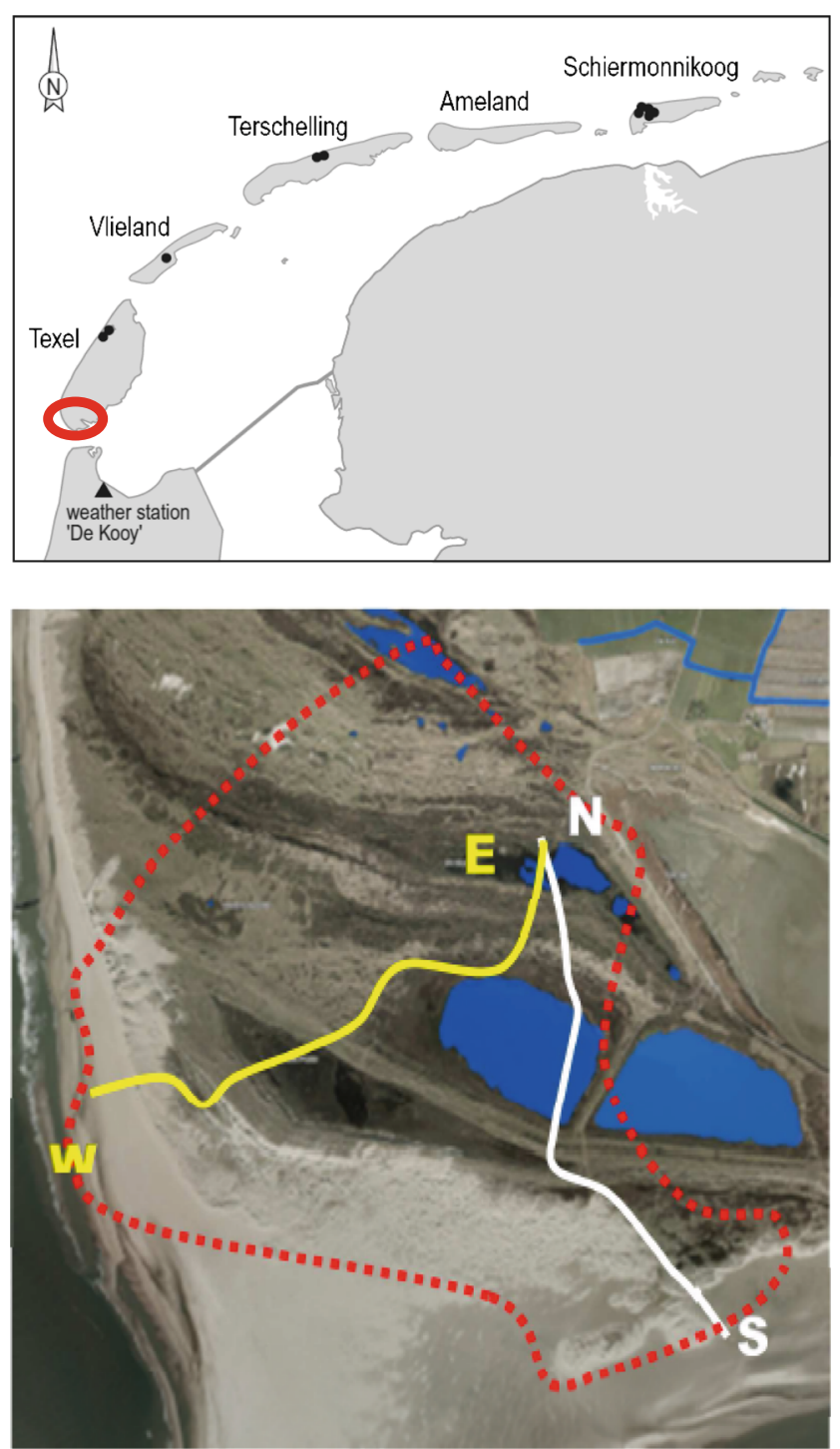

Fig. 1 The Dutch Wadden Sea island (top left) and position of study area (bottom left) on the southern part of Texel showing the research area and position of transects

population's size of L. loeselii on the German island of Borkum originate from (Petersen 2011, unpublished report).

\section{Population structure of $L$. loeselii on the hors (Texel)}

Within each site, four to seven sub-plots of $1 \times 1 \mathrm{~m}^{2}$ were sampled, the total number depending on the size of the populations. We assessed the population structure of $L$. loeselii by classifying the individuals found in each subplot into three life stages (cf. Oostermeijer and Hartman 2014): '1-leaf' for single-leaf juveniles, '2-leaf' for plants that had two leaves but no inflorescence, and 'adults' for plants that had flowered. The total number of $L$. loeselii individuals was also estimated at each site.

\section{Soil and vegetation sampling and soil analysis on the Dutch and German islands}

Across the Dutch and German Wadden islands, we sampled 23 sites (in triplicate) with occurrence of $L$. loeselii, 5 sites where the species had become extinct, and 4 sites where we expected the orchid to appear within a few years. In total, 96 samples were taken, using metal rings (volume of $100 \mathrm{~cm}^{3}$ ). Samples were weighed before drying at $40{ }^{\circ} \mathrm{C}-70{ }^{\circ} \mathrm{C}$ to measure the water content. The dried samples were then homogenized, sieved through a $2-\mathrm{mm}$ mesh and ground (5 $\mathrm{min}$ at $400 \mathrm{rpm}$ ) before drying (at $105{ }^{\circ} \mathrm{C}$ for $24 \mathrm{~h}$ ). Soil extracts were prepared by adding $100 \mathrm{~g}$ of soil to $100 \mathrm{~g}$ of distilled water. After shaking and centrifuging, the water extract was filtered using a $0.2 \mu \mathrm{m}$ membrane filter. This final water extract was then used to analyze the following variables: carbon fractions with the TOC analyzer (Shimadzu TOC-Vcph); pH, Electrical Conductivity (EC), anion concentration $\left(\mathrm{Cl}^{-}, \mathrm{PO}_{4}{ }^{3-}, \mathrm{NO}_{3}^{-}, \mathrm{NO}_{2}^{-}, \mathrm{DOC}, \mathrm{SO}_{4}{ }^{2-}, \mathrm{NH}_{4}^{+}\right)$, cation concentration $\left(\mathrm{Ca}^{2+}, \mathrm{Na}^{+}, \mathrm{K}^{+}, \mathrm{Mg}^{2+}, \mathrm{Al}^{3+}, \mathrm{Fe}, \mathrm{Mn}, \mathrm{P}, \mathrm{S}\right.$, $\mathrm{Si}, \mathrm{Zn}$ ) and alkalinity using Inductive Coupled Plasma Atomic Emission Spectrophotometry (ICP-AES). Total C and N contents were measured using a CNS elemental analyzer.

\section{Vegetation sampling and soil analysis on Texel (de $\mathbf{H}$ ors)}

Vegetation cover in the sub-plots was estimated using the Braun-Blanquet approach. We also estimated vegetation height and percentage cover of shrubs, herbs, bare soil and mosses. Water levels and thickness of the organic layer were measured in bore holes. Soil samples were taken using the $100 \mathrm{~cm}^{3}$ metal rings. The samples were pooled for a total volume of $200 \mathrm{~cm}^{3}$ and transported to the laboratory prior to analysis. In each sample, the amount of organic material, $\mathrm{pH}$, and water extractable $\mathrm{K}, \mathrm{Na}, \mathrm{Ca}, \mathrm{Mg}, \mathrm{Al}, \mathrm{Fe}, \mathrm{Mn}, \mathrm{Si}, \mathrm{NH}_{4}$, $\mathrm{PO}_{4}, \mathrm{Cl}, \mathrm{SO}_{4}$ and Dissolved Organic Carbon (DOC) was measured as mentioned before.

In total, 53 variables were measured in the Texel area, including parameters related to vegetation, fresh soil, those measured from the soil water extractions and water levels.

\section{Data analysis}

A Pearson correlation test was conducted to test for significant correlations between population age and these environmental parameters. L. loeselii populations were classified into 3 groups: (i) Extinct populations, (ii) Extant populations, and (iii) Predicted future populations. Extinct populations were Liparis populations that have been recorded at certain sites, but have disappeared before 2010. Populations that were found during our study period (2010-2013) were categorized as Extant. Predicted populations were expected to establish a population soon in a developing (young) dune slack (see Photo 1). Differences between groups with respect to the 

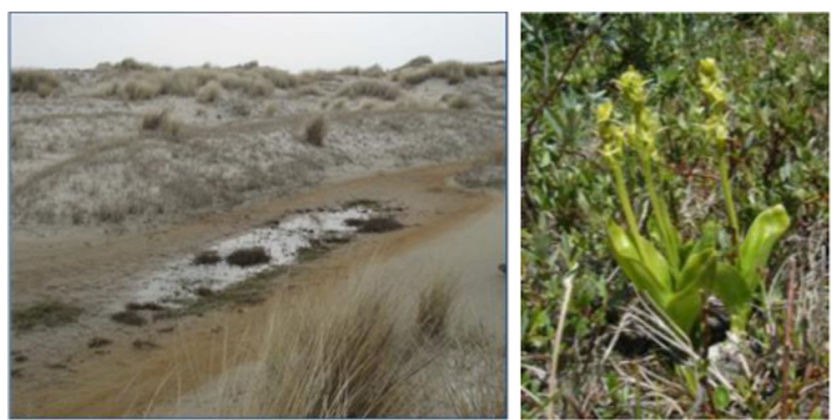

Photo 1 Photo of a very young dune slack on Texel (de Hors) where Liparis loesellii is not yet present, but can be expected within 5 years. Note the deposition of iron on the eastern shore line in particular, due to discharge of anoxic groundwater

environmental parameters were tested, using a One-way ANOVA, followed by the Bonferroni post-hoc test.

For multivariate analyses, we used the computer program, CANOCO (Ter Braak and Smilauer 2002). Detrended Correspondence Analysis (DCA) was first applied to the species composition data (data not shown). The vegetation data were square root transformed to minimize the effect of dominant species. Axes were detrended by segments and rare species were down-weighted. Based on the length of the gradients $(>4.0)$ estimated by DCA, the unimodal constrained ordination of Canonical Correspondence Analysis (CCA) was selected to analyze differences in $L$. loeselii occurrence. In the CCA analysis, scaling was focused on inter-sample distance and bi-plot scaling was applied. In order to find significant discriminating variables, we applied forward selection to all variables followed by a Monte-Carlo permutation test (999 permutations with a significance level of 0.05 ).

\section{Isohypse pattern of the dune system de hors (Texel)}

Lines of similar groundwater levels (isohypse patterns) in the Hors areas were based on data from a digital groundwater data base (Dinoloket, www.dinoloket.nl), which was supplemented with groundwater level measurements from 10 piezometers during 2013, morphological characteristics and hydrological calculations (Stuyfzand et al. 2014).

\section{Groundwater composition of dune water on de hors(Texel)}

Groundwater samples were taken at a range of depths below the groundwater table (GWT) from shallow borings (up to $3 \mathrm{~m}$ in depth) by means of a hand-driven hollow stem auger developed by the VU University Amsterdam. A hand pump is connected to the narrow bore tubing housed inside the auger, one end of which is attached to a small filter. Groundwater could thus be extracted from selected depths. For all lab measurements sampling depths were as follows: at $0.15 \mathrm{~m}, 0.60 \mathrm{~m}, 1.05 \mathrm{~m}$ and $1.5 \mathrm{~m}$-GWT. Groundwater sampling was done at 21 locations on 2 transect lines (Fig. 1). Groundwater was sampled during winter/early spring period and at the end of August 2013. The deeper groundwater from two existing deep water wells was also sampled discretely in September 2013.

\section{Hydrological modeling of freshwater lenses in the hors area (Texel)}

The hydrological modeling of the freshwater lens of the Hors area on Texel was carried out using the computer model HYDROLENS 3.2 (Stuyfzand 2009; Stuyfzand et al. 2014). Besides the general variables such as groundwater recharge, permeability, porosity, dune width or width of infiltration area, the following variables can also be adjusted in the model: system type (circular or elongated island or coastal strip), salinity (EC) or chloride (mg/l) and temperature of fresh and salt groundwater, the transversal dispersivity of sand, the change of dune width, and the expected sea level rise (SLR). Three scenarios were investigated, with an assumed beach slope of 0.0017: (i) scenario A: no sea level rise and no sand nourishment, (ii) scenario B: no sand nourishment, $1 \mathrm{~m}$ sea level rise, and (iii) scenario C: $1 \mathrm{~m}$ sea level rise, $800 \mathrm{~m}$ sand nourishment.

\section{Results}

\section{Liparis populations on the Dutch and German Wadden Sea islands}

In 2010 the highest number of individual of Liparis loeselii on the Wadden Sea islands were found on the island of Texel $( \pm$ 18,000 at the south-eastern part of the island, most of them occurring in dune slacks of 5-15 years old (Table 1). Also populations on the islands Terschelling $( \pm 1.440)$, and Schiermonnikoog ( \pm 900$)$ comprised a high number of individuals, in particular on newly formed beach plains. On the islands of Vlieland and Ameland, much fewer individuals were found, and only at a few sites. In total about ca. 20,000 individuals of L. loeselii were found on the Dutch Wadden Sea islands in 2010. On the German island Borkum more than 3000 individuals were counted in 2010, almost all at the eastern side of the island.

\section{Population structure and dune slack development on the hors (Texel)}

The number of individuals and population structure of this orchid were found to vary between the different successional stages (Fig. 2). Mean population sizes were low in the early (2y) and late (18y) successional stages, and highest in the 12 and $15 y$ old slacks. In the youngest population, the number of 2-leaved individuals was about the same as the number of juveniles, whereas in the $12 \mathrm{y}$ old populations, the number of 2-leaved individuals was the highest. At later stages, the 
Table 1 Number of individuals of Liparis loeselii counted in 2010 in various dune slacks on the Wadden Sea islands

\begin{tabular}{|c|c|c|c|}
\hline $\mathrm{Nr}$. & Wadden Sea island & Individuals & Successional age (yrs) \\
\hline 1 & Texel1 & \pm 460 & $1-5$ \\
\hline 2 & Texel2 & \pm 230 & 18 \\
\hline 3 & Texel3 & \pm 1350 & $8-15$ \\
\hline 4 & Texel4 & \pm 1120 & $5-10$ \\
\hline 5 & Texel5 & \pm 200 & $1-5$ \\
\hline 6 & Texel6 & $\pm 18,000$ & $1-5$ \\
\hline 7 & Texel7 & 25 & $>>10$ \\
\hline 8 & Texel8 & 9 & $>>10$ \\
\hline \multirow[t]{2}{*}{9} & Texel9 & \pm 160 & $>>10$ \\
\hline & Total Texel & $\pm 20,000$ & \\
\hline 10 & Vlieland1 & 66 & $5-10$ \\
\hline 11 & Vlieland2 & \pm 230 & $>80$ \\
\hline \multirow[t]{2}{*}{12} & Vlieland3 & 16 & $>20$ \\
\hline & Total Vlieland & \pm 312 & \\
\hline 13 & Terschelling1 & \pm 670 & $1-5$ \\
\hline \multirow[t]{2}{*}{14} & Terschelling2 & \pm 770 & $>10$ \\
\hline & Total Terschelling & \pm 1.443 & \\
\hline 15 & Ameland1 & \pm 210 & $5-10$ \\
\hline \multirow[t]{2}{*}{16} & Ameland2 & 34 & $>10$ \\
\hline & Total Ameland & \pm 244 & \\
\hline 17 & Schiermonnikoog1 & \pm 250 & $17-20$ \\
\hline 18 & Schiermonnikoog3 & \pm 300 & $1-5$ \\
\hline 19 & Schiermonnikoog4 & \pm 300 & $1-5$ \\
\hline \multirow[t]{2}{*}{20} & Schiermonnikoog5 & 6 & ca. 40 \\
\hline & Total Schiermonnikoog & \pm 850 & \\
\hline \multirow[t]{2}{*}{21} & Borkum1 & 2980 & $>25$ \\
\hline & Total Borkum & \pm 3000 & \\
\hline
\end{tabular}

numbers of adults and 2-leaved individuals fluctuated. Juveniles (1-leaved) had the lowest frequency at all stages.

The oldest site where $L$. loeselii has occurred was 34 years old in 2010 (Table 1) but $L$. loeselii disappeared from this site about 12 years earlier. Before its disappearance, the population at this site was estimated to be at least 20 years old. The oldest

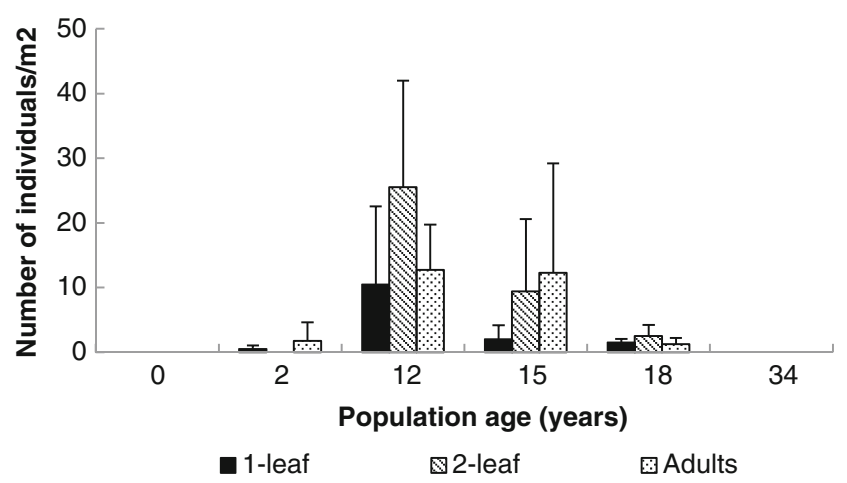

Fig. 2 Population structure of $L$. loeselii according to age of population on the Hors, Texel. Error bars in the bar graph indicate standard deviation age estimated for the extant populations was 18 years, whereas the youngest population was estimated to be 2 years old. The time needed for $L$. loeselii to colonize a new dune slack on this part of Texel, therefore, varied between 2 to 25 years. Based on the results of the oldest slack, we estimated that the life span of L. loeselii populations in this area is probable about 20 years.

\section{L. loeselii Populations and environmental factors on Texel (de hors)}

The variables that are significantly correlated with population age are shown in Table 2. Positive correlations were found between population age and total vegetation cover, carbon (C), dissolved organic carbon (DOC), total organic carbon (TOC), sodium/calcium ratio (Na:Ca), potassium and aluminum, whereas negative correlations were found with percentage cover of bare sand, $\mathrm{pH}$, alkalinity and silica (Table 2). Depth of organic matter (OM), carbon, $\mathrm{pH}$ and silica all differed significantly between sites with the three different types of populations (Extinct, Extant and Expected; Table 3). Both thickness of the organic layer (from $4.3 \pm 2 \mathrm{~cm}$ to $10 \pm 2.1 \mathrm{~cm}$ ) and the amount of carbon was higher in Extinct than in Extant sites.

\section{L. loeselii Populations and environmental factors on the Wadden Sea islands}

The CCA-biplot of all 96 sampled sites on the six Wadden Sea islands (Fig. 3) reveals results similar to the local study on Texel: the amount of Organic Matter in the soil (SOM), the $\mathrm{pH}$, and $\mathrm{Cl}$, $\mathrm{Fe}$, and $\mathrm{Al}$ concentrations in the soil water are the most differentiating environmental factors explaining variability among the sites. Optimal occurrence of $L$. loeselii is best explained by a high $\mathrm{pH}$ and a low amount of organic matter. Local extinction of the orchid is best explained by a low $\mathrm{pH}$, and high concentrations of $\mathrm{Al}$ and $\mathrm{Fe}$ (not significant). Sites at which $L$. loeselii can be expected in the near future are characterized by high $\mathrm{NH}_{4}{ }^{+}$, $\mathrm{SO}_{4}{ }^{2-}$ and $\mathrm{Cl}^{-}$concentrations in the soil water.

\section{Hydrological system at the hors (Texel)}

The contour lines of groundwater levels of the southern part of Texel (Fig. 4) show that the highest water levels of the Hors area are situated at the western Hors lake, indicating that this part of the island is forming a relatively small hydrological subsystem that has no or little relation with the main hydrological system of Texel.

The calcium and chloride concentrations of the groundwater in a transect from North to South are shown in Fig. 5. There is a local water divide below the high dune at the right side of Fig. 5, with groundwater discharging into the sea to the left, and into the Wadden Sea (via the Geul) to the right. The chloride distribution shows that fresh groundwater $(\mathrm{Cl}<300 \mathrm{mg} / \mathrm{l})$ is present above the extensive clay layer at a depth of $<10 \mathrm{~m}$ 
Table 2 Mean and standard deviation for the environmental variables measured on the Island of Texel at sites where L. loeselii used to occur (Extinct populations), occur now (Extant populations) and are expected to occur (Predicted populations). All variables were significantly different for the site types

\begin{tabular}{llll}
\hline & $\begin{array}{l}\text { Extinct population } \\
\text { Mean } \pm \mathrm{SD}\end{array}$ & $\begin{array}{l}\text { Extant population } \\
n=39 \\
\text { Mean } \pm \mathrm{SD}\end{array}$ & $\begin{array}{l}\text { Expected population } \\
(n=4) \\
\text { Mean } \pm \mathrm{SD}\end{array}$ \\
\hline Variables & $1.9 \pm 2.6^{\mathrm{a}}$ & $8 \pm 10.7^{\mathrm{a}}$ & $71 \pm 14^{\mathrm{b}, \mathrm{c}}$ \\
\hline Bare sand cover (\%) & $86.3 \pm 57^{\mathrm{a}}$ & $44 \pm 43^{\mathrm{a}, \mathrm{c}}$ & $15 \pm 6.2^{\mathrm{b}, \mathrm{c}}$ \\
Moisture (\%) & $10 \pm 2.1^{\mathrm{a}}$ & $4.3 \pm 2^{\mathrm{b}}$ & 0 \\
Organic matter layer (cm) & $100.1 \pm 37.5^{\mathrm{a}}$ & $51.9 \pm 30.7^{\mathrm{b}}$ & $6.9 \pm 0.8^{\mathrm{c}}$ \\
Organic carbon (kmol/m2) & $14,528 \pm 355^{\mathrm{a}}$ & $675 \pm 316^{\mathrm{b}, \mathrm{d}}$ & $307 \pm 101^{\mathrm{c}, \mathrm{d}}$ \\
Dissolved organic carbon (mmol) & $4624 \pm 529^{\mathrm{a}}$ & $2879 \pm 1505.8^{\mathrm{b}, \mathrm{d}}$ & $351 \pm 92^{\mathrm{c}, \mathrm{d}}$ \\
Nitrogen (mmol/m $\left.{ }^{2}\right)$ & $80.99 \pm 11.77^{\mathrm{a}}$ & $38.91 \pm 20.89^{\mathrm{b}, \mathrm{d}}$ & $8.6 \pm 6.9^{\mathrm{c}, \mathrm{d}}$ \\
Ammonium (mmol) & $14.27 \pm 4.27^{\mathrm{a}}$ & $4.9 \pm 4.4^{\mathrm{b}, \mathrm{d}}$ & $2.65 \pm 0.92^{\mathrm{c}, \mathrm{d}}$ \\
Phosphorus (mmol) & $5.4 \pm 0.6^{\mathrm{a}}$ & $6.7 \pm 0.4^{\mathrm{b}}$ & $8.1 \pm 0.2^{\mathrm{c}}$ \\
pH(KCl) & $5.68 \pm 1.40^{\mathrm{a}}$ & $1.49 \pm 0.60^{\mathrm{b}, \mathrm{d}}$ & $2.60 \pm 1.62^{\mathrm{c}, \mathrm{d}}$ \\
Sodium/Calcium ratio & $60.67 \pm 18.33^{\mathrm{a}}$ & $32.18 \pm 16.52^{\mathrm{a}, \mathrm{c}}$ & $16.34 \pm 5.71^{\mathrm{b}, \mathrm{c}}$ \\
Potassium (mmol) & $1.34 \pm 0.45^{\mathrm{a}}$ & $0.62 \pm 0.33^{\mathrm{b}, \mathrm{d}}$ & $0.39 \pm 0.38^{\mathrm{c}, \mathrm{d}}$ \\
Aluminum (mmol) & $0.18 \pm 0.10^{\mathrm{a}}$ & $0.09 \pm 0.09^{\mathrm{a}, \mathrm{c}}$ & $0.02 \pm 0.01^{\mathrm{b}, \mathrm{c}}$ \\
Manganese (mmol) & $4.02 \pm 1.05^{\mathrm{a}}$ & $10.83 \pm 2.2^{\mathrm{b}}$ & $16.97 \pm 2.78^{\mathrm{c}}$ \\
Silica (mmol) & $0.04 \pm 0.01^{\mathrm{a}}$ & $0.02 \pm 0.01^{\mathrm{b}, \mathrm{d}}$ & $0.01 \pm 0^{\mathrm{c}, \mathrm{d}}$ \\
Zinc (mmol) & & & \\
\hline
\end{tabular}

below sea level. The lowest chloride and calcium values are present under the youngest dunes near the sea.

\section{Simulation of the volume of the water lens at different scenarios}

The calculated form of the fresh water lens in the southern part of Texel (including parts of the main groundwater system) shows that the fresh water lens shrinks in volume when sea level would rise with $1 \mathrm{~m}$ (Fig. 6a). However, when prior to this rise sand nourishment is applied (in front of the beach) creating an extension of the beach by $800 \mathrm{~m}$ (of which $260 \mathrm{~m}$ is eroded later), then the fresh water lens expands considerably (Fig 6b). The boundary between fresh water and salt water is set at $50 \%$ mixing between fresh and salt water.

Table 3 Partial correlation coefficients for variables that are significantly correlated with population age of Liparis loeselii $(P<0.05)$

\begin{tabular}{ll}
\hline Environmental variable & Correlation coefficient \\
\hline Total vegetation cover $(\%)$ & 0.393 \\
Bare sand cover $(\%)$ & -0.459 \\
$\mathrm{C}$ & 0.463 \\
$\mathrm{DOC}$ & 0.587 \\
$\mathrm{TOC}$ & 0.523 \\
$\mathrm{pH}(\mathrm{KCl})$ & -0.614 \\
$\mathrm{Alkalinity}$ & -0.399 \\
$\mathrm{Na}: \mathrm{Ca}$ & 0.474 \\
$\mathrm{~K}$ & 0.555 \\
$\mathrm{Al}$ & 0.518 \\
$\mathrm{Si}$ & -0.615 \\
\hline
\end{tabular}

\section{Discussion}

\section{Dune-slack succession and window of opportunity for $L$. loeselii}

Our results on the island of Texel showed that the window of opportunity for L. loeselii to establish a population was relatively narrow, less than 20 years, but that this species is still able to take advantage of this narrow window. Populations

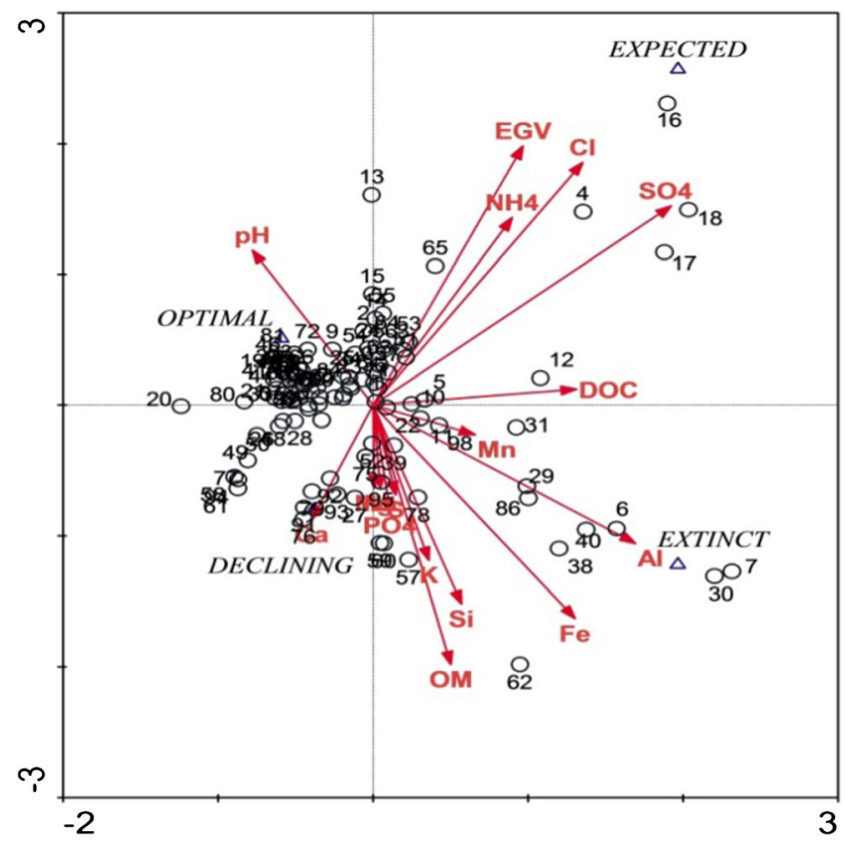

Fig. 3 A CCA-biplot of 96 sites and 14 environmetal variables explaining the status of Liparis-populations (expected, extinct, declining, optimal) on 6 Wadden Sea islands 
Fig. 4 Isohypse map of the phreatic groundwater table August-September 2013) at the south-east part of Texel (the Hors)

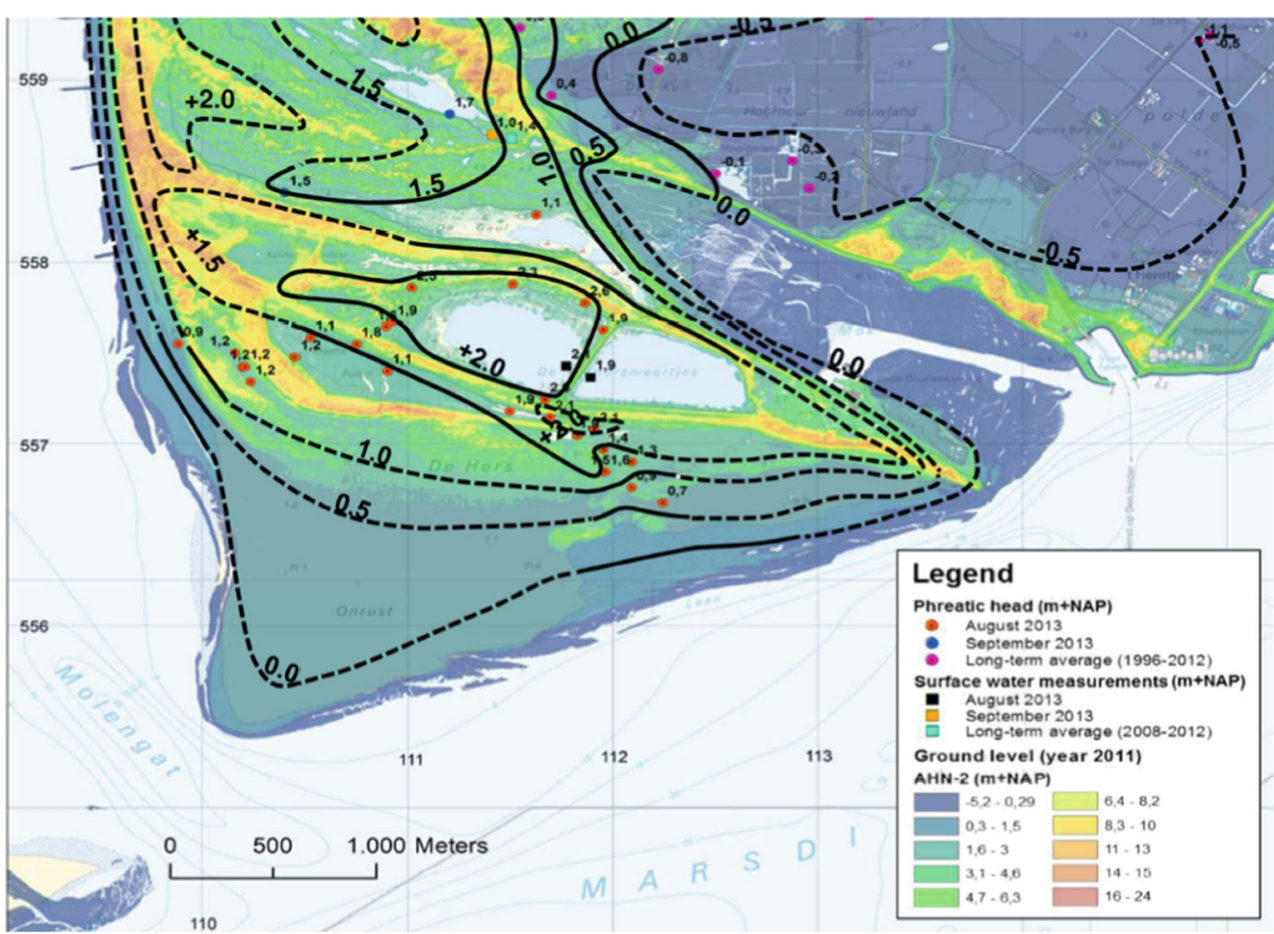

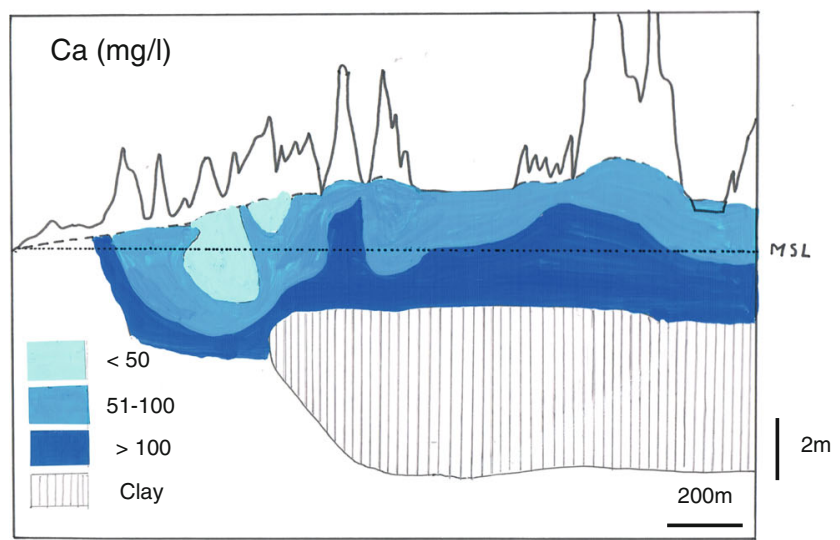

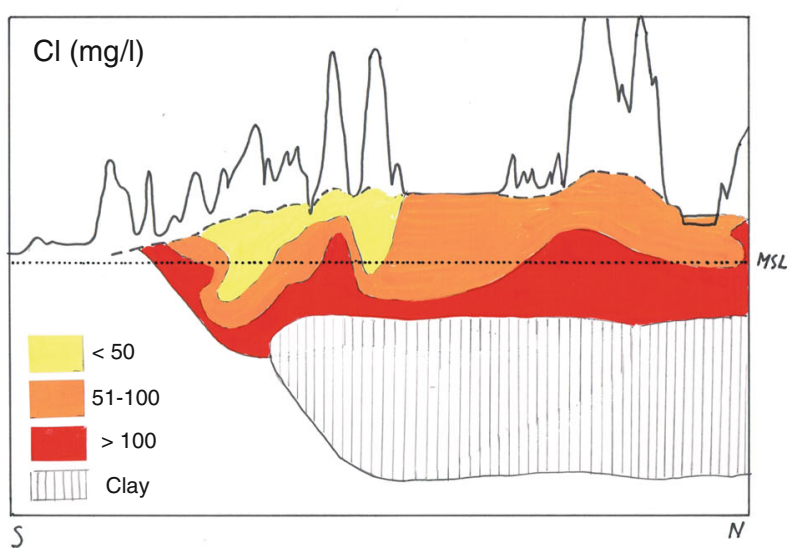

Fig. $5 \mathrm{Ca}$ and $\mathrm{Cl}$ concentrations in the shallow groundwater in transect S-N on Texel, de Hors), measured in August 2013. MSL = Mean sea water level were able to colonize newly formed slacks at very early stages. Two years after a slack has become vegetated, L. loeselii is already able to establish small populations. Sometimes, it was able to establish even before the slack formation had completely finished. This indicates that $L$. loeselii is a well-dispersed species, and can colonize new sites easily,

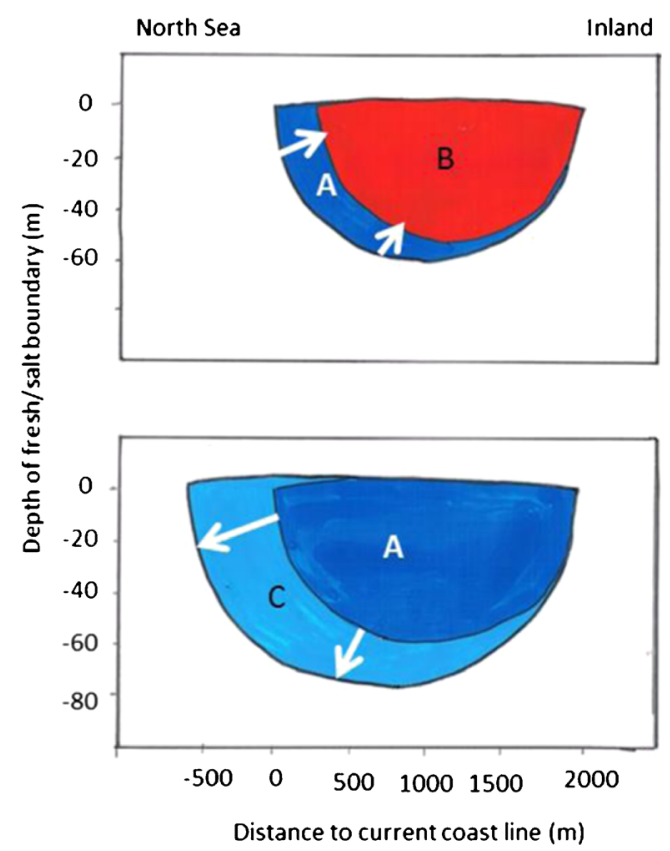

Fig. 6 Simulation results of volume of freshwater lense as influenced by sea level rise and sand nourishment on Texel, de Hors. Scenario $\mathrm{a}=$ present situation (dark blue), $\mathrm{b}=$ sea level rise of $1 \mathrm{~m}$ without sand nourishment (red). $\mathbf{c}=$ sea level rise of $1 \mathrm{~m}$ with sand nourishment (light blue; increase of coast line by sand nourishment is $800 \mathrm{~m}$ ) 
as suggested by Jones (1998). A high number of individuals at the 2-leaf stage could be a positive indication for the populations in this study, as mortality was shown to be high at earlier stages (54\% per year) for L. loeselii populations in the UK (Wheeler et al. 1998). A study on Dutch fen and dune slack populations also showed that populations of both types are generally short-lived, between 10 and 15 years (Oostermeijer and Hartman 2014).

The number of individuals in L. loeselii populations may fluctuate considerably. On the German island of Borkum the numbers fluctuated from c. 800 to ca 11,000 within four years (Petersen 2011, unpublished report). The short window of opportunity for $L$. loeselii during (natural) succession in the Hors area could only be extended modestly (ca. 5-10 years) by a management regime of annual mowing in the oldest dune slacks. By comparison, populations on a beach plain on the German Wadden Sea island Borkum survived for more than 30 years without any management intervention (Petersen 2012, unpublished report).

\section{Key environmental factors for $L$. loeselii}

Our study confirms that $L$. loeselii prefers intermediate stages of vegetation succession and does not tolerate habitats with frequent flooding by seawater, as indicated by a significant correlation with the $\mathrm{Na} / \mathrm{Ca}$ ratio. However this may not be a causal relationship. Grootjans et al. (2014) reported sites with abundant occurrence of $L$. loeselii, at which chloride contents could be as high as $13.4 \mathrm{mmol} / \mathrm{l}$. Apparently, adult individuals of $L$. loeseli are quite tolerant to occasional high chloride concentrations, particularly during winter. Probably, such high concentrations are quickly diluted with fresh rain or discharge water in wet dune slacks surrounded by taller dunes. Furthermore, during winter the plants survive in bulbs, and are less vulnerable for inundation with sea water.

We found a negative effect of soil organic matter on the survival of $L$. loeselii populations, as has been reported by previous studies (e.g. Wotavová et al. 2004; Janečková et al. 2006). In our study area, the extinct populations were associated with sites with high organic matter. The accumulation of organic matter in the soil alters many soil properties, such as soil moisture and $\mathrm{pH}$, and consequently also has a large impact on mineralization rates (Berendse et al. 1998). Also the high concentrations of $\mathrm{Fe}$ in declining and extinct population could be an indirect effect of increased accumulation of organic matter. The amount of iron stored in the soil increases with increasing slack age. High iron concentrations might not be a direct cause of the decline of the orchid.

The preference of the species for habitats with a high $\mathrm{pH}$ $(>6)$ is consistent with results of other studies (e.g. Wheeler 1998, Oostermeijer \& Hartman 2014). In particular, the density of juvenile (1-leaved) individuals was strongly positively correlated with Ellenberg's $\mathrm{pH}$ indicator value in Dutch dune slacks (Oostermeijer \& Hartman 2014). Consequently, this orchid will head into decline when a dune slack accumulates organic matter and starts to acidify. However, the ecological mechanism that leads to the decline of $L$. loeselii populations during acidification is still unknown. Dijk and Eck (1995), while studying another orchid species of partly the same habitat, Dactylorhiza incarnata, suggested that ammonium $\left(\mathrm{NH}_{4}{ }^{+}\right)$toxicity was responsible for the decline of that species. Van den Berg et al. (2005) reported a similar result for the decline of species sensitive to acidity, such as Antennaria dioica and Succisa pratensis. Our field study appears consistent with this hypothesis on ammonium toxicity for $L$. loeselii since $\mathrm{NH}_{4}{ }^{+}$and $\mathrm{pH}$ were inversely correlated to each other in our CCA analysis. However, further study is needed to confirm this putative mechanism for the decline of $L$. loeselii after acidification.

Surprisingly, we did not find that water levels were important for the occurrence of $L$. loeselii populations in wet dune slacks on the scale of all islands, since various authors have suggested that disruption of the hydrology has a detrimental effect on $L$. loeselii. However, locally water levels may be very relevant in several ways. First, adult individuals don't seem to cope well with very high water levels during the growing season (Oostermeijer and Hartman 2014). On the other hand, high water levels play an important role in maintaining the calcareous environment and the regulation of organic matter (Adema et al. 2005). Depending on the dominant species in a young dune slack, high (mean) water levels can lead to almost no accumulation of organic matter or even to peat formation (Shahrudin et al. 2014). When Littorella uniflora dominates the vegetation its root zone is oxygenated and nutrient availability is maintained at a very low level. Because of its ability to actively oxygenating the soil, L. uniflora is able to keep the pioneer stage stable for many decades (Adema et al. 2005). However, when the highly productive Phragmites australis becomes the dominant species, the topsoil remains anoxic and the dead plant remains are preserved. Shahrudin et al. (2014) reported that L. loeselii can (re-colonize) these very old dune slacks ( $>90$ years old) when the peat layer is more than $20 \mathrm{~cm}$ and Phragmites australis becomes less dense. This occurred even without a mowing management. The site was actually a living peatland (fen) where $\mathrm{pH}$ was kept at a high level (above 6) and nutrient availability was restricted by the very high water levels (anoxic conditions).

Factors that lead to low water levels, such as extracting drinking water, drainage and afforestation, as well as increasing length of dry periods will negatively affect populations of L. loeselii. Low water levels promote desiccation, which triggers the invasion of highly productive grasses or shrubs (Adema et al. 2005), which accelerate the accumulation of organic matter and increase acidification. On the other hand, a longer inundation period may hinder seed recruitment since 
mycelia of the mycorrhizal fungus that is associated with L. loeselii cannot grow under anaerobic conditions (Read et al. 1998). This is congruent with the observations reported by Oostermeijer and Hartman (2014). We probably did not find a negative effect of flooding because the summer of 2010 was not very wet. Additionally, as our dune slacks are still very young, decalcification may not yet have occurred and the soil itself is still buffered against acidification.

\section{Hydrological system of the hors area}

The isohypse map of August 2013 for the southern part of Texel, appear to indicate that the main groundwater system of this part of the island, does not, or in a modest way, supply our study area with groundwater. The discharging groundwater in the northern dune slacks is drained by natural drainage systems and transported to the sea. So, the dune slacks in the Hors areas are supplied with groundwater from rather local hydrological systems, with rather thin groundwater lenses (5$10 \mathrm{~m}$ ). This can be concluded from the chemical composition of the groundwater at different depths (Fig. 5, Fig. 7). The chloride and calcium concentrations have a similar pattern. Low values were found in the young dunes and high values at greater depths and under the high dunes at the right of Fig. 5. The low values in the young dunes can be explained by the scarce vegetation cover of these dunes (see Photo 1 ). Non-vegetated dunes trap less salt spray than vegetated ones. That could explain the low chloride concentrations. Also the production of $\mathrm{CO}_{2}$ in the root zone is very low and therefore little calcium can be dissolved in the calcareous dunes. Another reason is that the low Ca groundwater clearly shows cation exchange due to fresh water intrusion $(\mathrm{Ca}$ being

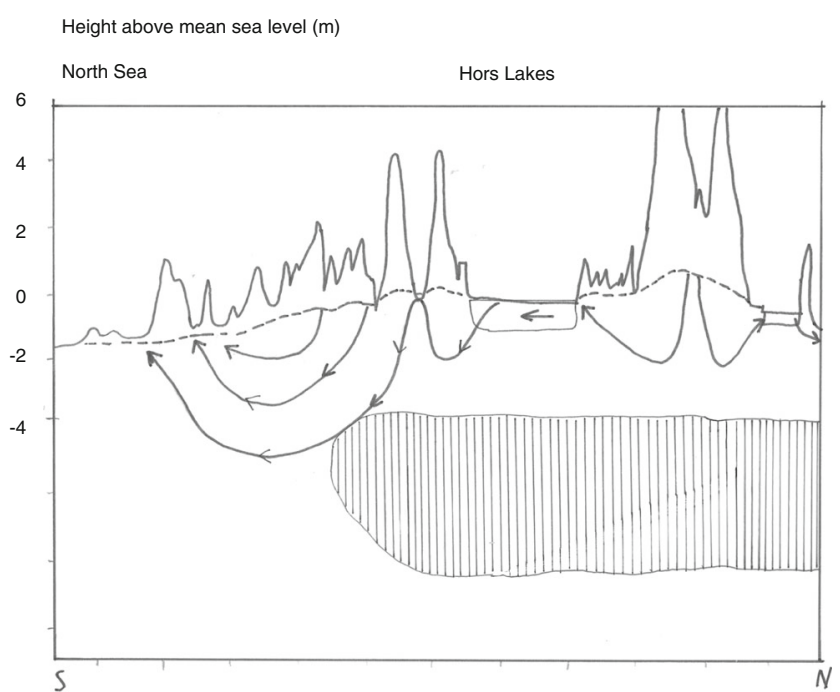

Fig. 7 Conceptual model of groundwater flow in the Hors area (Texel), based on the calcium and chloride concentrations in the shallow groundwater (Fig. 5) in transect S-N, de Hors, Texel absorbed and $\mathrm{Na}+\mathrm{K}+\mathrm{Mg}$ being desorbed), which is consistent with the low $\mathrm{Cl}$ levels.

The hydrological system analysis also showed that several dune slacks in the Hors area functioned as "flow-through lakes". The western Hors lake, for instance is permanently flooded, but is receiving groundwater from the northern and north-western dunes, while it supplies the eastern Hors lake and several southern dune slacks with groundwater for most of the year. The most western dunes slacks also receive groundwater from a large dune slack more to the east (Kreeftenpolder), but this supply of groundwater stops when this large slack falls dry during the summer (Stuyfzand et al. 2014).

\section{Long-term survival of Liparis loeselii on the Wadden Sea islands}

The information from this study is important when considering the fact that inland populations of this orchid are declining due to massive habitat alterations such as conversion of land for agricultural purposes. Coastal dune slacks nowadays receive much attention in conservation strategies (Davy et al. 2006) and dune slacks may represent one of the last refuges for L. loeselii in Western Europe. The situation in the United Kingdom demonstrates the importance of dune slack habitats for the survival of this species. About $90 \%$ of the UK population is now only found in the coastal sand dunes of South Wales and population decline in this habitat is also dramatic (Jones et al. 1995, Jones 1998). Dune stabilization was one of the factors that caused the decline of the UK populations (Jones et al. 1995). Since coastal sand dunes are a dynamic habitat compared to fen habitats, this indicates that the dynamic nature of these habitats is important for the survival of this species. The importance of dynamic processes in dune formation was also shown by Petersen (2011, 2012, unpublished reports) who assessed rather stable populations on the island of Borkum (Germany. This is only possible when populations can easily move between old sites and new ones within a larger area undergoing dynamic dune forming processes. Therefore, it is very important not to interfere with or restrain the natural processes leading to the formation of new dune slacks.

In order for a metapopulation to work in such a dynamic habitat, the relatively high extinction rates suggested by the short population life spans need to be compensated by equally high colonization rates. Several population genetic studies (Pillon et al. 2007, Shahrudin 2014, Vanden Broeck et al. 2014) provide support for the good seed dispersal although the genetic structure is affected strongly by the spontaneous self-pollination of the species. Assignment tests of juvenile individuals to their most likely population of origin suggest that even though most dispersal occurs over relatively short distances, much longer distances of $>100 \mathrm{~km}$ are bridged 
occasionally (Shahrudin 2014, Vanden Broeck et al. 2014). Hence, vacant habitat patches are probably colonized quite rapidly in most cases, although we have also observed on Terschelling that a dune slack was suitable for at least 10 years before it was successfully colonized by the species. Given the above, this is remarkable, because the nearest seed source was found less than $35 \mathrm{~km}$ away.

\section{Decalcification and acidification}

On the Wadden Islands, decalcification of dunes once fixed by vegetation, is a relatively rapid process (Stuyfzand 1993), because of the low primary $\mathrm{CaCO}_{3}$ content of $0.5 \%$ (Texel) to $1.2 \%$ (Schiermonnikoog). With a simple mass balance Stuyfzand et al. (2014) calculated for Texel a decalcification rate of $0.56 \mathrm{~m} /$ century above the groundwater table and $0.15 \mathrm{~m} /$ century below it, for a bare dune lacking eolian inputs of calcareous sand, and $0.73 \mathrm{~m} /$ century above the groundwater table and $0.26 \mathrm{~m} /$ century below it, for a dune fixed by dune grasses and mosses.

This means that fen orchid, with a rooting depth of about $0.1 \mathrm{~m}$, will root in decalcified, acidified dune sand already after 14-18 years, provided that local groundwater is steadily replenished by rainfall (thus not exfiltrating). On Schiermonnikoog this would take a bit longer, namely 1,2 / $0,5 \times(14-18)=34-43$ years.

Acidification will rapidly follow after decalcification, because the acid front is moving downwards about 3-10 times faster than the decalcification front. The arrival of the acid front is manifested in soil moisture and groundwater by a sharp drop in $\mathrm{pH}, \mathrm{Ca}$ and $\mathrm{HCO}_{3}$, and a sharp increase for among others $\mathrm{Al}$ and $\mathrm{SiO}_{2}$. We therefore conclude that decalcification and nearly simultaneous acidification form an excellent explanation of declining populations of fen orchid on older dunes without (sufficient) eolian inputs of calcareous sand and without exfiltration of calcareous groundwater. This is in harmony with the statistical results.

\section{Implications for management}

In systems with regular formation of dune slacks, management is not required to keep a metapopulation of $L$. loeselii viable over a long time span. Metapopulation models have shown that management to prolong the life span of individual populations, such as mowing to maintain an open vegetation structure, can increase viability to a modest extent, because seed sources remain active for quite some time (Grootjans et al. 2014).

In existing fixed dune complexes, promotion of secondary dune slack formation through blow-outs is the most natural and cost-effective strategy to maintain viable metapopulations of early to mid-successional species. However, achieving just enough wind erosion leading to blow-outs in a fixed dune complex is a challenge. But when no or very few new slacks are formed, overlap in time may be lacking and local extinction might occur as was described by Jones (1998) for several sites at the coast of Wales. Under such conditions, new introductions from population of other islands might be helpful in sustaining the metapopulation.

Our hydrological research on Texel revealed that most dune slacks with Liparis populations were fed by calcareous and anoxic groundwater from rather small hydrological systems. These systems are vulnerable to sea level rise, which leads to a narrower beach plain, shrinking of the groundwater lenses and reducing the discharge of groundwater. Sand nourishment before the water line not only prevents erosion of the beach and dune areas, but may even temporary increase the discharge of groundwater to the newly-formed dune slack, when the groundwater lens of the island is expanding in reaction to sand nourishment.

Acknowledgments The Dutch knowledge network OBN (survival of Dutch Nature) is acknowledged for financing most of the research presented here (project OBN 2012-33-DK).

Open Access This article is distributed under the terms of the Creative Commons Attribution 4.0 International License (http:// creativecommons.org/licenses/by/4.0/), which permits unrestricted use, distribution, and reproduction in any medium, provided you give appropriate credit to the original author(s) and the source, provide a link to the Creative Commons license, and indicate if changes were made.

\section{References}

Adema EB, Van de Koppel J, Meijer HAJ, Grootjans AP (2005) Enhanced nitrogen loss may explain alternative stable states in dune slack succession. Oikos 109:374-386

Berendse F, Lammerts EJ, Olff H (1998) Soil organic matter accumulation and its implications for nitrogen mineralization and plant species composition during succession in coastal dune slacks. Plant Ecol 137:71-78

Bzdon G, Ciosek M (2006) Fen orchid L. loeselii loeselii (L.) rich. In abandoned gravel-pit in Dąbrówka Stany near Siedlice (Poland). Biodiv Res Conserv 1-2:193-195

Davy AJ, Grootjans AP, Hiscock K, Peterson J. (2006) Development of eco-hydrological guidelines for dune habitats - Phase 1. English Nature Research Reports, No 696, Peterborough

Dijk E, Eck N (1995) Ammonium toxicity and nitrate response of axenically grown Dactylorhiza incarnata seedlings. New Phytol 131: 361-367

Grootjans, AP, Stuyfzand PJ H. Everts FH, De Vries NPJ. Kooijman AM, Oostermeijer JGB Nijssen, M, Wouters, B, Petersen, J \& Shahrudin, R. (2014) Ontwikkeling van zoet-zoutgradiënten met en zonder dynamisch kustbeheer; een onderzoek naar de mogelijkheden voor meer natuurlijke ontwikkelingen in het kustgebied. VBNE-rapport 2014/OBN193-DK.

Janečková P, Wotavová K, Schödelbauerová I, Jersáková J, Kindlmann P (2006) Relative effects of management and environmental conditions on performance and survival of populations of a terrestrial orchid, Dactylorhiza majalis. Biol Cons 129:40-49

Jones PS, Etherington JR (1992) Autoecological studies on the rare orchid L. loeselii loeselii and their application to the management of 
dune slack ecosystems in South Wales. In: Carter RWG, Curtis TGF, Sheehy SMJ (eds) Coastal dunes, geomorphology, ecology and management for conservation. Rotterdam, Balkema pp, pp. 299312

Jones PS, Kay QON, Jones A (1995) The decline of rare plant species and community types in the sand dune system of South Wales. In: Healy MG, Doody JP (eds) Directions in European coastal management. Samara Publishing Limited, Cardigan, UK, pp. 547-555

Jones PS (1998) Aspects of the population biology of $L$. loeselii loeselii (L.) Rich. Var. ovata Ridd. ex Godfrey (Orchidaceae) in the dune slacks of South Wales. UK Bot J Linn Soc 126:123-139

Lammerts EJ, Grootjans AP (1998) Key environmental variables determining the occurrence and life span of basiphilous dune slack vegetation. Acta Bot Neerl 47:369-392

McMaster RT (2001) The population biology of L. loeselii loeselii, Loesel's Twayblade, in a Massachusetts wetland. Northeast Nat 8: $163-178$

Milanović D (2012) L. loeselii Loeselii (L.) rich. - a plant rediscovered in the Balkan peninsula. Bot Serb 36:85-89

Naczk A, Minasiewicz J (2010) Morphological and ecological differentiation of selected populations of $L$. loeselii Loeselii (L.) L. C. Rich. (Orchidaceae) in the Pomorze Gdańkie region. (in polish with English abstract and summary) Acta bot. Cassub 7-9:147-160

Oostermeijer JGB, Hartman Y (2014) Inferring population and metapopulation dynamics of Liparis loeselii from single-census and inventory data. Acta Oecol 60:30-39

Pawlikowski P (2008) Distribution and population size of the threatened fen orchid L. loeselii loeselii (L.) Rich. in the Lithuanian Lake District (NE Poland). Bot. Stec.12:53-59

Petersen J (2000) Die Dünentalvegetation der Wattenmeer-Inseln in der südlichen Nordsee. Eine pflanzensoziologische und ökologische Vergleichsuntersuchung unter Berücksichtigung von Nutzung und Naturschutz. 336 pp., Husum

Pillon Y, Qamaruz-Zaman F, Fay M, Hendoux F, Piquot Y (2007) Genetic diversity and ecological differentiation in the endangered fen orchid (Liparis loeselii). Cons Genet 8:177-184

Read FRS, Morgan A, Shaw SC (1998) Aspects of the seed biology and germination ecology of $L$. loeselii loeselii var. ovata.. CCW Science Report No. 255, Countryside Council for Wales
Schnittler M, Günther K-F (1999) Central European vascular plants requiring priority conservation measures - an analysis from national red list and distribution maps. Biodiv Cons 8:891-925

Shahrudin R (2014) Do we really need management to preserve pioneer stages in wet dune slacks? Dissertation University of Groningen, pp. 104

Stuckey IH (1967) Environmental factors and the growth of native orchids. Americ J Bot 54:232-241

Stuyfzand PJ (1993) Hydrochemistry and hydrology of the coastal dune area of the Western Netherlands. PhD Thesis Free University of Amsterdam, published by KIWA, ISBN 90-74741-01-0, p. 366

Stuyfzand PJ (2009) HYDROLENS 3.1: A 2D hydrological model for analytical approximation of the size and shape of either fresh groundwater lenses on saline water, or rain water lenses on infiltrated river water. Set in Excel spreadsheet. Open source

Stuyfzand PJ,I Estrada de Wagt, Amatirsat D, Bland C, Oskam B, Van Loon D, Everts FH, Grootjans, AP (2014) Zoet-zout gradiënten op 4eilanden, in hydrologisch en hydrogeochemisch perspectief. KWR Watercycle Research Institute Nieuwegein, The Netherlands, (BTO 2014.221(s), pp 141

Ter Braak CJF, Smilauer P (2002) CANOCO reference manual and CanoDraw for Windows user's guide: software for canonical community ordination (version 4.5). Ithaca, NY, USA: Microcomputer Power

Van den Berg LJL, Dorland E, Vergeer P, Hart MAC, Bobbink R, Roelofs JGM (2005) Decline of acid-sensitive plant species in heathland can be attributed to ammonium toxicity in combination with low $\mathrm{pH}$. New Phytol 166:551-564

Vanden Broeck A, Van Landuyt, W., Cox, K, Gyselings R, De Bruyn L, Mergeay J. (2014). De groenknolorchis (Liparis loeselii L.); zaadverbreiding en lokale adaptatie. Rapporten van het Instituut voor Natuur- en Bosonderzoek (INBO.R.2014.1561208). Instituut voor Natuur- en Bosonderzoek, Brussel, ISSN: 1782-9054

Wheeler BD, Lambley PW, Geeson J. (1998) Liparis loeselii loeselii (L.) Rich, in eastern England: constraints on distribution and population development. Bot. J. Linn. Soc.126:141-158

Wotavová K, Balounová Z, Kindlmann P (2004) Factors affecting persistence of terrestrial orchids in wet meadows and implications for their conservation in a changing agricultural landscape. Biol Cons 118:271-279 